\title{
EDUCAÇÃO DE JOVENS E ADULTOS: ASPECTOS TEÓRICOS/METODOLÓGICOS
}

\section{ARTIGO ORIGINAL}

JESUS, Daniela de ${ }^{1}$

LOPES, Juliana Waltrick ${ }^{2}$

COSTA, Morgana da Luz ${ }^{3}$

BASTOS, Sadi Ricardo da Silva ${ }^{4}$

LOCKS, Geraldo Augusto ${ }^{5}$

LIMA, Lucia Ceccato de ${ }^{6}$

JESUS, Daniela de. Et al. Educação de Jovens e Adultos: Aspectos Teóricos/Metodológicos. Revista Científica Multidisciplinar Núcleo do Conhecimento. Ano 05, Ed. 10, Vol. 06, pp. 136-168. Outubro de 2020. ISSN: 2448-

${ }^{1}$ Graduação em andamento em Pedagogia.

2 Graduação em andamento em Pedagogia.

${ }^{3}$ Graduação em andamento em Pedagogia.

4 Orientadora. Mestrado em Educação. Especialização em Desporto Coletivo. Graduação em Educação Física.

${ }^{5}$ Orientador. Doutorado em Antropologia Social. Mestrado em Antropologia Social. Especialização em Educação e Movimentos Sociais. Especialização em Educação Popular. Aperfeiçoamento em Pós-Doutoramento em Educação. Graduação em Teologia. Graduação em Ciências Sociais.

6 Orientadora. Doutorado em Engenharia Ambiental. Mestrado em Educação. Especialização em Metodologia da Pesquisa. Especialização em Educação. Aperfeiçoamento em Biotecnologia. Graduação em Ciências Biológicas. 
0959,

Link

de

acesso: https://www.nucleodoconhecimento.com.br/educacao/aspectos-teoricos

\section{RESUMO}

Este artigo tem a finalidade de refletir acerca da Alfabetização de Jovens e Adultos desenvolvida na cidade de Lages, estado de Santa Catarina, no que concerne ao conhecimento das metodologias de ensino desenvolvidas e descrição das dificuldades encontradas pelos educadores em suas práticas de alfabetização. Trata-se de uma pesquisa quanti-qualitativa, descritiva, incluindo trabalho de campo com realização de uma entrevista estruturada com a professora regente do curso de Alfabetização de Jovens e Adultos, e preenchimento de um formulário organizado por eixo, com dez estudantes contendo perfil, alfabetização e aspectos teóricos/metodológicos. O embasamento teórico está referenciado e autores como Brandão et al, Ferrari, Fonseca e Paulo Freire, entre outros. A análise dos dados recolhidos demonstrou a relevância da formação continuada dos professores que atuam com esta modalidade de ensino, tendo em foco a área da andragogia, ou seja, atentar para as especificidades das práticas educativas singulares e estratégias distintas, com vistas ao preenchimento de lacunas na aprendizagem e uma educação cidadã.

Palavras-chave: Educação de Jovens e Adultos, alfabetização, metodologias, dificuldades.

\section{INTRODUÇÃO}

A Educação de Jovens e Adultos tem longa história no país. Perpassa a história do Brasil, no seu período colonial, imperial e republicano. Detém um marco legal nacional e internacional, definindo diretrizes e programas de alfabetização em cada período, caracterizada atualmente como uma modalidade de ensino.

A Educação de Jovens e Adultos tem grande relevância, pois por vezes passa despercebida pela sociedade em geral e é exatamente nessa modalidade de ensino que encontramos um grande número de pessoas que não tiveram acesso aos bancos 
escolares na idade adequada e que buscam na escola, uma oportunidade de melhoria da qualidade de vida.

Após um certo período de tempo alguns retornam ao ambiente escolar, provocando curiosidade no motivo pelo qual voltaram a estudar. A EJA seria um dos grandes auxiliadores na retomada. Sendo assim, indagamos nesta investigação, como os professores alfabetizam e quais são as metodologias utilizadas neste processo de ensino na EJA? Por meio dessa indagação busca-se compreender as formas de alfabetização na EJA de Lages (SC); verificar as metodologias de ensino existentes; identificar o processo de alfabetização dos jovens e adultos e descrever as dificuldades encontradas pelo professor para desenvolver o processo de alfabetização nesta modalidade de ensino.

Trata-se de uma pesquisa quanti-qualitativa, descritiva, incluindo trabalho de campo com realização de uma entrevista com a professora regente da Alfabetização de Jovens e Adultos, e preenchimento de um formulário com os estudantes, organizado por eixos, contendo, perfil, alfabetização e aspectos teóricos/metodológicos. O embasamento teórico está referenciado e autores como Brandão et ali, Ferrari, Fonseca, Paulo Freire, entre outros.

\section{CONHECENDO A PRÁTICA DA EJA EM LAGES, SC}

Durante o processo de pesquisa na EJA de Lages, SC, foram utilizadas duas técnicas para a coleta de dados. Com a professora regente da turma foi realizada uma entrevista estruturada e com 10 estudantes, um formulário. Todos os envolvidos nesta pesquisa são moradores de Lages (SC), a professora possui Graduação em Pedagogia e Pós-Graduação/Especialização em Educação Especial, há dois anos que trabalha na modalidade da EJA, e é Admitida em Caráter Temporário (ACT).

As perguntas que introduzem os gráficos foram divididas por eixos: perfil, alfabetização, aspectos teóricos/metodológicos e avaliação, tendo como objetivo conhecer como ocorreu a alfabetização na EJA e suas dificuldades. No decorrer das 
análises será explanado também sobre as respostas da professora participante, fazendo a relação com as informações coletadas junto aos estudantes.

\section{PERFIL}

GRÁFICO 1: sexo

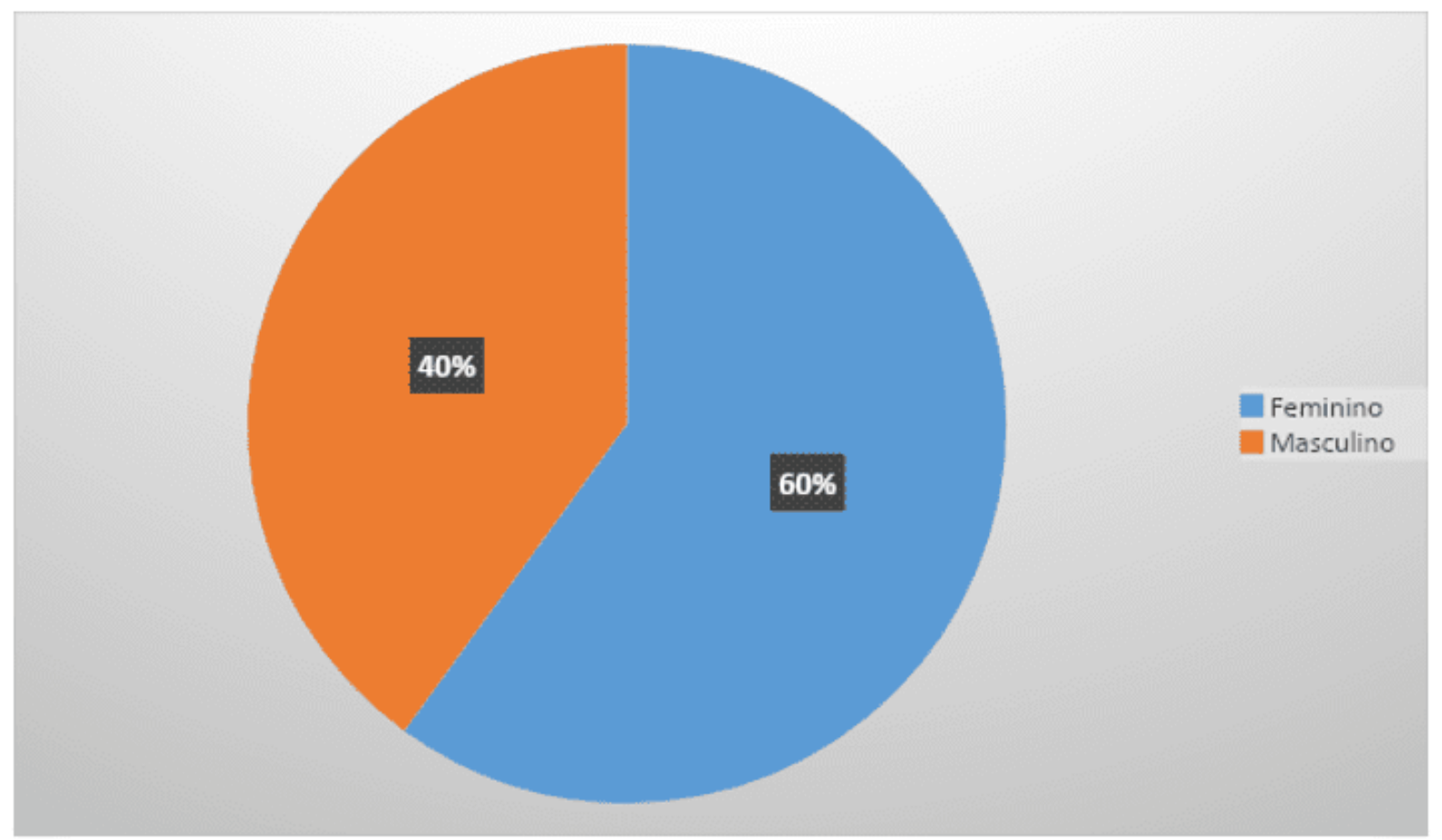

Fonte: Pesquisa realizada em uma escola estadual de Lages/SC em 2019.

Conforme apresentado no gráfico, $60 \%$ dos formulários respondidos foram do sexo feminino e $40 \%$ masculino. Na sociedade conforme o IBGE (2018) o número de mulheres no Brasil, Estado de Santa Catarina é de 50,38\%, enquanto o gênero masculino é de 49,62\%. A maioria da população catarinense identificadas são mulheres. Dessa forma, fica evidente o público alvo dos estudantes ser do sexo feminino, além do mais, durante o processo de análise de dados foi observado que o maior número de pessoas que participou da pesquisa foi do sexo feminino, pois muitas não puderam estudar na idade certa por preconceito do pai, marido, gravidez na adolescência ou por optar em não continuar seus estudos, voltando depois de certa idade aos bancos escolares e buscando assim conhecimento. 
GRÁFICO 2: faixa etária

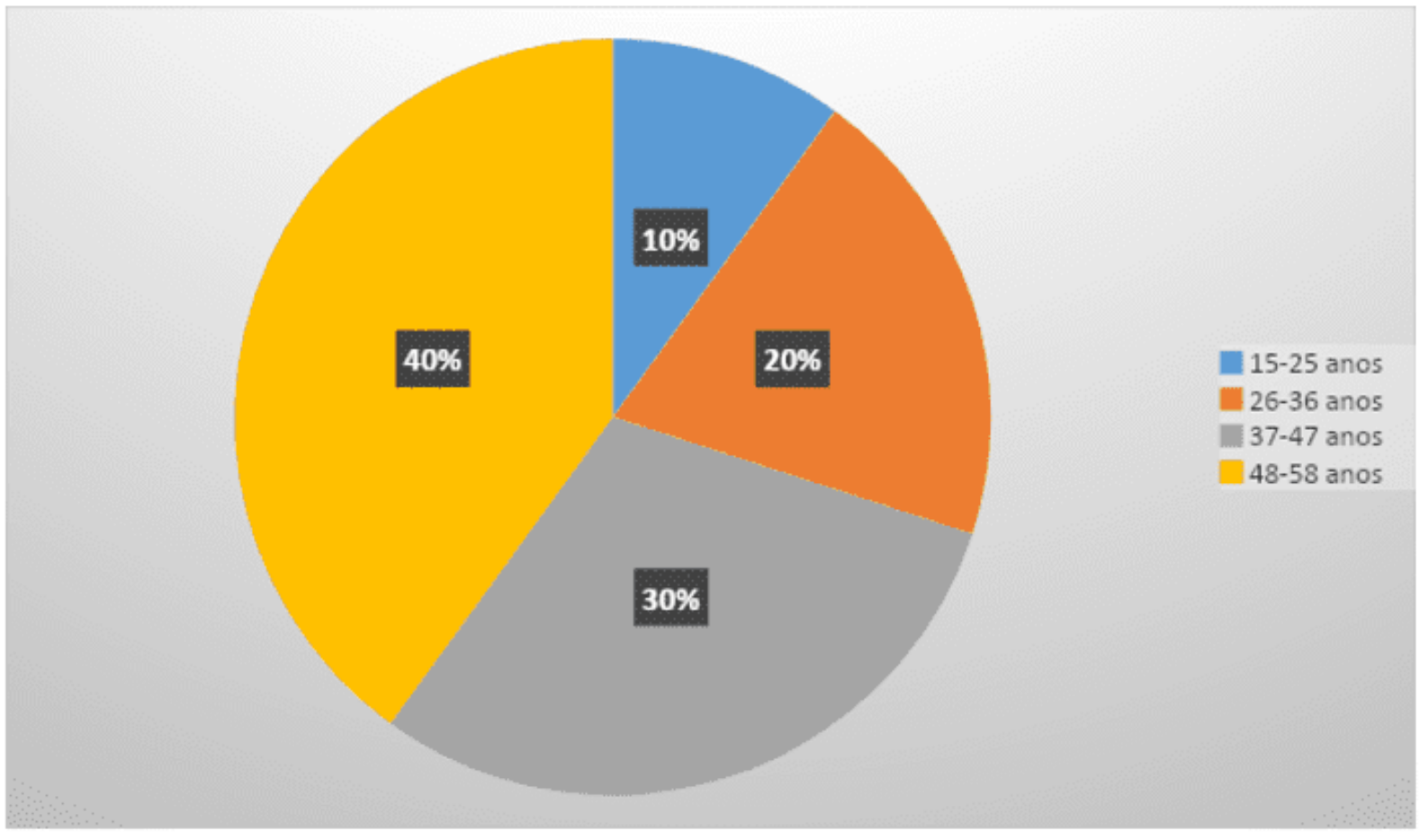

Fonte: Estudantes da modalidade da EJA em uma escola estadual em Lages/SC em 2019 .

De acordo com o gráfico a faixa etária dos respondentes varia entre 15 anos e acima de 59 anos, sendo $40 \%$ entre 48 e 59 anos, 30\% entre 37 e 47 anos, $20 \%$ entre 26 e 36 anos e $15 \%$ entre 15 e 25 anos.

A educação de Jovens e Adultos é formada por estudantes com faixa etária bem diversificada, em geral um público com a idade mais avançada, pois viveram numa época onde o acesso à escola era mais difícil. Conforme legislação da LDB (1996), a faixa etária para a inserção dos indivíduos na EJA é de 15 anos para Ensino Fundamental e 18 anos para Ensino Médio.

Alguns estudantes enfrentam dificuldades para chegar até a escola, já outros, para aumentar a renda familiar trabalhavam o dia todo, sendo assim, deixando de concluir seus estudos. A chegada do primeiro filho na adolescência também afastou algumas jovens da sala de aula, quando conseguem voltar a frequentar as escolas, o que resta é a educação de Jovens e Adultos. 
Outro fator importante em relação à faixa etária dos estudantes da EJA é a metodologia que o professor utiliza, se condiz com a idade de seus alunos, levando em consideração que são indivíduos distintos, não infantilizando esses jovens e adultos.

Um dos impasses que a professora enfrenta em sala de aula é relacionada a faixa etária dos alunos, ela conta: "é difícil a idade que a gente trabalha pra uma criança de pré com a cabeça de pré do que meus alunos que eu tenho aqui". Quando esses jovens e adultos voltam a estudar, se deparam com outra realidade, com faixas etárias um pouco diversificada, e dessa forma a professora precisa saber mediar os saberes de acordo com a realidade de seus alunos. Como descreve Paraná (2006, p. 27) " essa modalidade de ensino possui uma clientela diversificada com relação à faixa etária, a situação socioeconômica e cultural, ao tipo de ocupação que exerce e o motivo pelo qual ingressaram na EJA". Sendo assim, à professora responsável pela turma deve conhecer seus estudantes para mediar os conhecimentos de forma clara e eficaz, a idade dos estudantes precisa ser levada em consideração na alfabetização bem como a mediação de conteúdos.

GRÁFICO 3: profissão

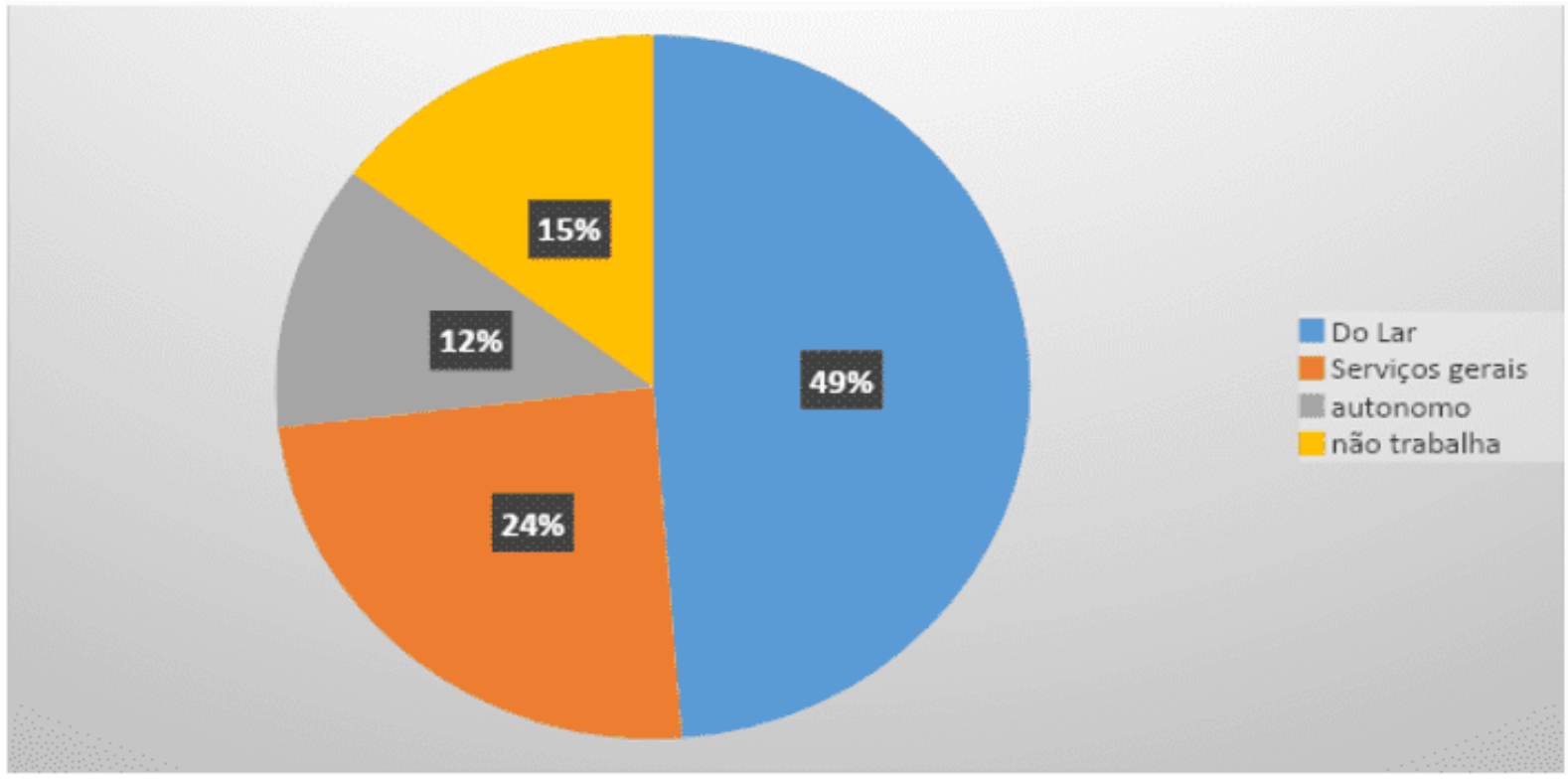

Fonte: Estudantes da modalidade da EJA em uma escola estadual em Lages/SC em 2019. 
Dos pesquisados, $49 \%$ responderam pela ocupação do lar, $24 \%$ são auxiliares de serviços gerais, $15 \%$ não trabalha e $12 \%$ são autônomos. É na modalidade de Educação de Jovens e Adultos que encontramos um grande número de pessoas que não tiveram acesso aos bancos escolares na idade adequada e que buscam na escola uma melhor condição de vida, aquisição de novos saberes, tirar $\mathrm{CNH}$, novas oportunidades de emprego, entre outras. Entretanto, no meio do caminho, existem barreiras, dificuldades que acabam fazendo com que esse público venha desistir de permanecer em sala ou até mesmo tenha dificuldades de frequentar as escolas.

Uma das grandes dificuldades de jovens e adultos que levam a desistência ou um número de faltas excessivo é a questão profissional, pois muitos trabalham o dia todo, e a noite estão cansados, ou tem filhos, casas para cuidar. Conforme Araújo (2009, p. 48) "o trabalho parece ter invadido todos os poros da vida, ocupando parte do tempo e das preocupações do trabalhador [...]". Dessa forma, apesar de muitos buscarem melhores condições de vida através do trabalho e estudo, muitos desistem devido à rotina diária.

De forma geral, percebe-se que os dados que mais obteve destaque entre os entrevistados foi a ocupação do lar, outras são autônomas, e alguns não trabalham, sendo assim não apresentam tanta dificuldade para estar em sala, pois fazem seu próprio horário e se encontram na Educação de Jovens e Adultos para alcançar maiores chances e oportunidades de entrar e se manter no mercado de trabalho, conquistando uma profissão que lhes dê satisfação. 


\section{ALFABETIZAÇÃO}

GRÁFICO 4: em qual ano parou de estudar antes de voltar para a sala de aula?

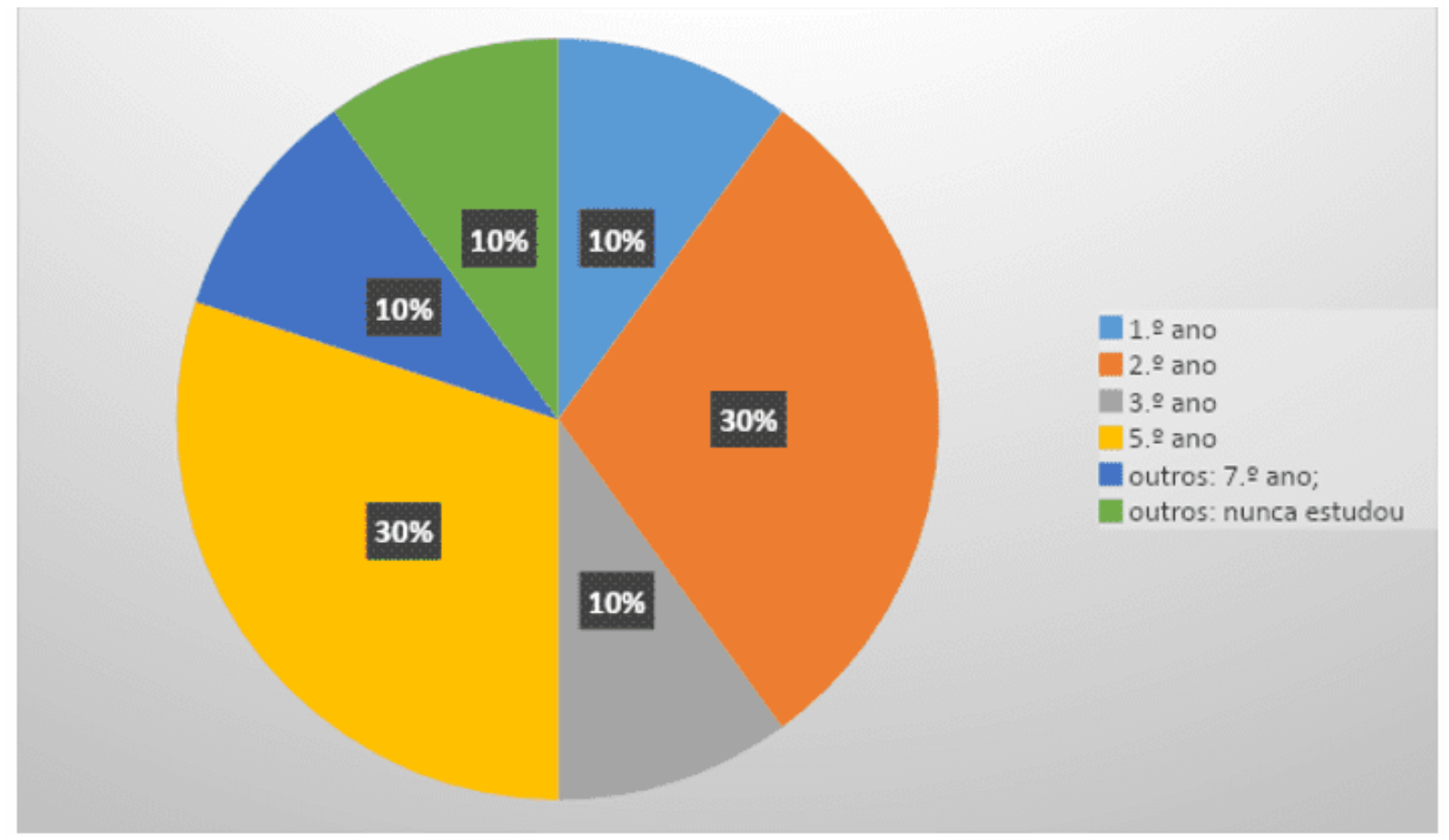

Fonte: Estudantes da modalidade da EJA em uma escola estadual em Lages/SC em 2019.

Conforme informações coletadas por meio de formulários, $48 \%$ dos estudantes pararam de estudar no $1 .$. ano do ensino fundamental, $17 \%$ frequentaram até o $2 . .0$ ano e $5 .$. ano; $6 \%$ deles estudaram até o $3 . .0$ ano e $7 . .0$ ano, e destes $6 \%$ nunca estudaram.

Por meio das informações representadas no gráfico, alguns indivíduos não chegam a frequentar os bancos escolares ou não conseguiram concluí-los. Com a criação de documentos norteadores, todos passam a ter direito a estarem na escola. De acordo com o artigo 205 da Constituição Federal, a educação, é direito de todos e dever do Estado e da família, será promovida e incentivada com a colaboração da sociedade visando ao pleno desenvolvimento da pessoa, seu preparo para o exercício da cidadania e sua qualificação para o trabalho (BRASIL, 1998). Independente da condição social que o indivíduo se encontre, o Estado deve assegurar os seus direitos 
como cidadão, principalmente o de estar no ambiente escolar onde deverá ter um ensino de qualidade.

Por motivos variados os indivíduos participantes da pesquisa relataram que pararam de estudar em determinados anos, fazendo com que seja considerado o nível de dificuldade em permanecer no ambiente escolar. Na Lei de Diretrizes e Bases da Educação Nacional - LDB 9394/96 nos Art.37 e 38 descreve sobre a EJA e seus direitos:

Art.37. A educação de jovens e adultos será destinada àqueles que não tiveram acesso ou continuidade de estudos no ensino fundamental e

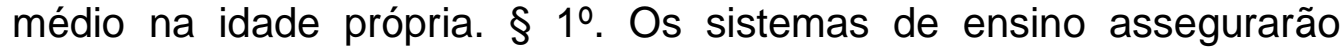
gratuitamente aos jovens e aos adultos, que não puderam efetuar os estudos na idade regular, oportunidades educacionais apropriadas, consideradas as características do alunado, seus interesses, condições de vida e de trabalho, mediante cursos e exames. § 2. O Poder Público viabilizará e estimulará o acesso e a permanência do trabalhador na escola, mediante ações integradas e complementares entre si. Art. 38. Os sistemas de ensino manterão cursos e exames supletivos, que compreenderão a base nacional comum do currículo, habilitando ao prosseguimento de estudos em caráter regular". (BRASIL, 1996, p. 16).

Independentemente do ano que o indivíduo parou seus estudos, ele tem direito a voltar a estudar, sendo a EJA um local gratuito, sem taxas para frequentar a sala de aula como também as provas de Exame Nacional Para Certificação de Competências de Jovens e Adultos (ENCCEJA) que ocorrem uma vez por ano, gerando assim o certificado de conclusão. Sendo garantido seus direitos pelo Estado. 
GRÁFICO 5: porque desistiu de estudar?

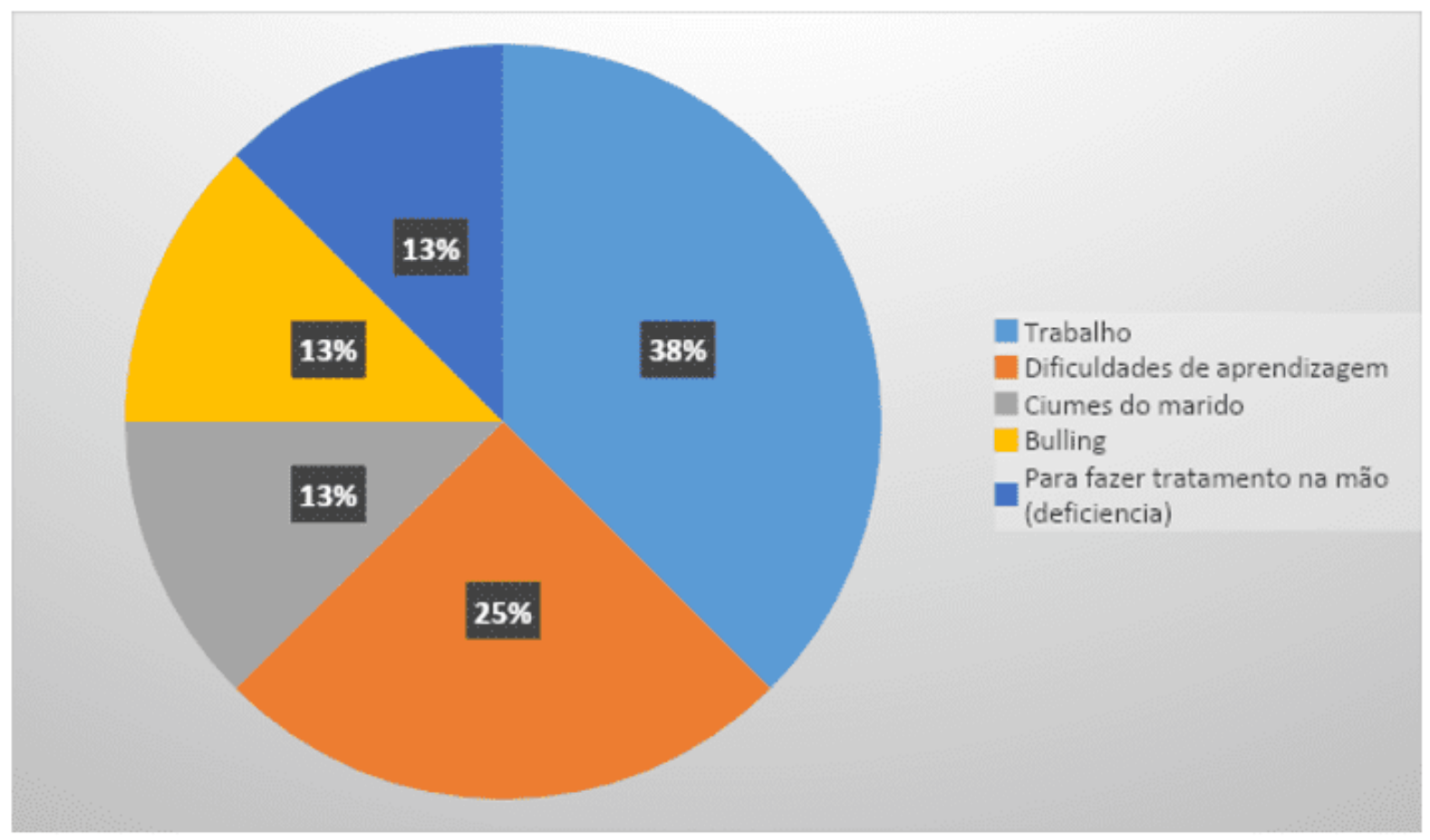

Fonte: Estudantes da modalidade da EJA em uma escola estadual em Lages/SC em 2019.

Os informantes da pesquisa foram questionados os motivos pelos quais pararam de estudar e $37 \%$ dos estudantes desistiram de estudar por razão do trabalho, e $25 \%$ pelas dificuldades de aprendizagem, já $13 \%$ por ciúmes do marido, 13\% bullying, e $13 \%$ (deficiência). Diante das informações, percebe-se que o fator que mais se evidenciou no gráfico, foi o motivo do trabalho, como um empecilho de dar continuidade nos bancos escolares. De acordo com o Instituto Brasileiro de Geografia e Estatística - IBGE (2017):

A Educação de Jovens e Adultos (EJA) era frequentada em 2007, ou anteriormente, por cerca de 10,9 milhões pessoas, o que correspondia a $7,7 \%$ da população com 15 anos ou mais de idade. Das cerca de 8 milhões de pessoas que passaram pela EJA antes de 2007, 42,7\% não concluíram o curso, sendo que o principal motivo apontado para o abandono foi a incompatibilidade do horário das aulas com o de trabalho ou de procurar trabalho $(27,9 \%)$, seguido pela falta de interesse em fazer o curso $(15,6 \%)$. 
É notável, que o fator que mais contribui para que os estudantes da EJA, abandonem os estudos, é o trabalho. Em observação com esse público, nota-se que foi necessário trabalhar muito cedo, sendo preciso escolher entre o estudo e a família.

O estudo desenvolvido por Meksenas (1998, p. 98) sobre evasão escolar dos alunos dos cursos noturnos, aponta por sua vez que a evasão escolar destes alunos se dá em virtude de serem "obrigados a trabalhar para sustento próprio e da família exaustos da maratona diária e desmotivados pela baixa qualidade do ensino, muitos adolescentes desistem dos estudos sem completar o curso secundário". Nesse sentido, o indivíduo acaba escolhendo parar com os estudos e arrumar um trabalho para ajudar nas finanças de seu lar.

Um outro elemento que afeta na continuidade dos estudos em relação aos estudantes da EJA é a questão da dificuldade de aprendizagem, como se pode perceber destacada no gráfico acima $25 \%$ desistiram por sentirem dificuldades de aprendizagem, relatam que pelo autoritarismo por parte dos docentes ficavam com receio de perguntar, fazendo com que parassem de frequentar a escola. Para os autores Martin e Marchesi (1996, p. 41) as dificuldades de aprendizagem seriam:

Relacionadas à dificuldade dos alunos para colocar em prática, rotinas de planejamento e controle dos processos cognitivos, envolvidos na realização de uma dada tarefa. Essas dificuldades são consideradas como níveis de menor realização, decorrentes do uso inapropriado dos mecanismos do processamento da informação; e não proveniente de deficiências de capacidade ou inteligência.

As dificuldades dos estudantes, por vezes é resultado da metodologia utilizada pelos docentes, sem levar às formas de compreensão diversificada de cada um dos indivíduos que estão em sala. Haydt (2004, p.7) aponta que: “(...) Cabe ao professor reconhecer as diferenças na capacidade de aprender dos alunos, para poder ajudálos a superar suas dificuldades e avançar na aprendizagem". É indispensável que o professor conheça seus alunos de tal forma que consiga diferenciar cada aluno, compreendendo a individualidade, respeitando o momento e a maneira como aprendem, consequentemente fazendo com que superem as dificuldades e prossigam na aprendizagem. 
Dos participantes $13 \%$ pararam de frequentar a escola por terem casado e o marido não permitir que estudassem, 13\% por terem uma deficiência e 13\% por sofrerem bullying em sala.

Fini (1996, p.73) cita que:

O ensino de má qualidade, o preconceito e o estigma podem contribuir para que 0 aluno possa apresentar comportamentos considerados difíceis e rendimento insuficiente academicamente e acabe por ser reprovado. Determinadas situações podem mesmo contribuir para que 0 aluno evite a escola, chegando até a evasão definitiva.

A desistência escolar, está ligado a cultura que o indivíduo está inserido, pois como consta na pesquisa até pelo preconceito do marido as mulheres não puderam dar continuidade nos seus estudos, outros por terem deficiência e não se sentirem parte daquele espaço desistindo assim de frequentar a escola.

GRÁFICO 6: o que fez retornar à escola?

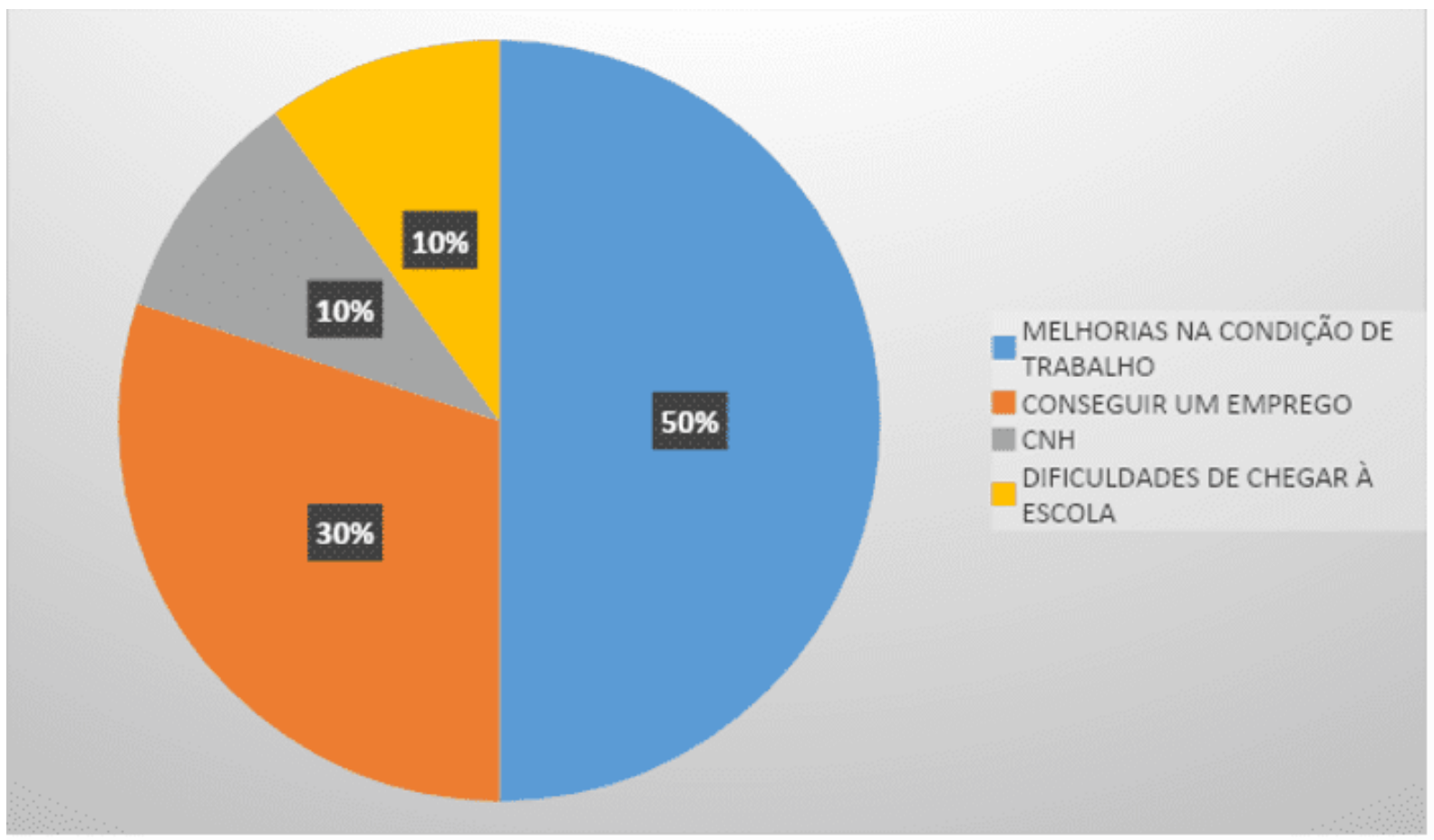

Fonte: Estudantes da modalidade da EJA em uma escola estadual em Lages/SC em 2019. 
Com base nas informações no gráfico pode-se constatar que $50 \%$ dos participantes da pesquisa retornaram à escola em busca de conhecimentos para melhorarem suas condições de trabalho, como por exemplo uma promoção. Os $30 \%$ pretendem conseguir um emprego. "A necessidade de emprego é um dos motivos mais fortes, pois assim como é motivo para evasão, também se torna um dos motivos para o retorno à sala de aula" (BRASIL, 2006, p.20), e 10\% planejam adquirir a CNH e ajudar os filhos nas tarefas escolares. Todos os indivíduos que retornam à sala de aula voltam por algum motivo relacionada a uma melhoria em sua vida, podendo ser no aspecto familiar ou pessoal.

Por fim, a professora foi indagada sobre quanto tempo os estudantes permanecem no nível nivelamento. Ela respondeu dizendo que ficam de 10 a 5 meses depende do tempo de cada um, e muitos vão ali para socializar passar o tempo e conversar.

Segundo Freire (1996, p. 71): "o educador que escuta aprende a difícil lição de transformar o seu discurso, às vezes necessário, ao aluno, em uma fala com ele". A instituição escolar precisa equacionar o que deseja ensinar, com o que os educandos já sabem, o que desejam saber e o que não julgam significativo às suas vidas.

Contudo, os estudantes da modalidade da EJA, buscam retornar aos bancos escolares, dando uma volta por cima em suas vidas, de tal forma que ocasione mudanças, para si e para sua família. Retomando sonhos, objetivos e necessidades da vida cotidiana, conseguindo assim, fazer parte dessa sociedade alfabetizada. Sabendo do grande número de analfabetos que não buscam essa retomada escolar, pode-se notar com essa pesquisa, que os estudantes são motivados, e verdadeiros vencedores por permanecerem em sala 


\section{ASPECTOS TEÓRICOS/METODOLÓGICOS}

GRÁFICO 7: recurso utilizado para alfabetizar é adequado?

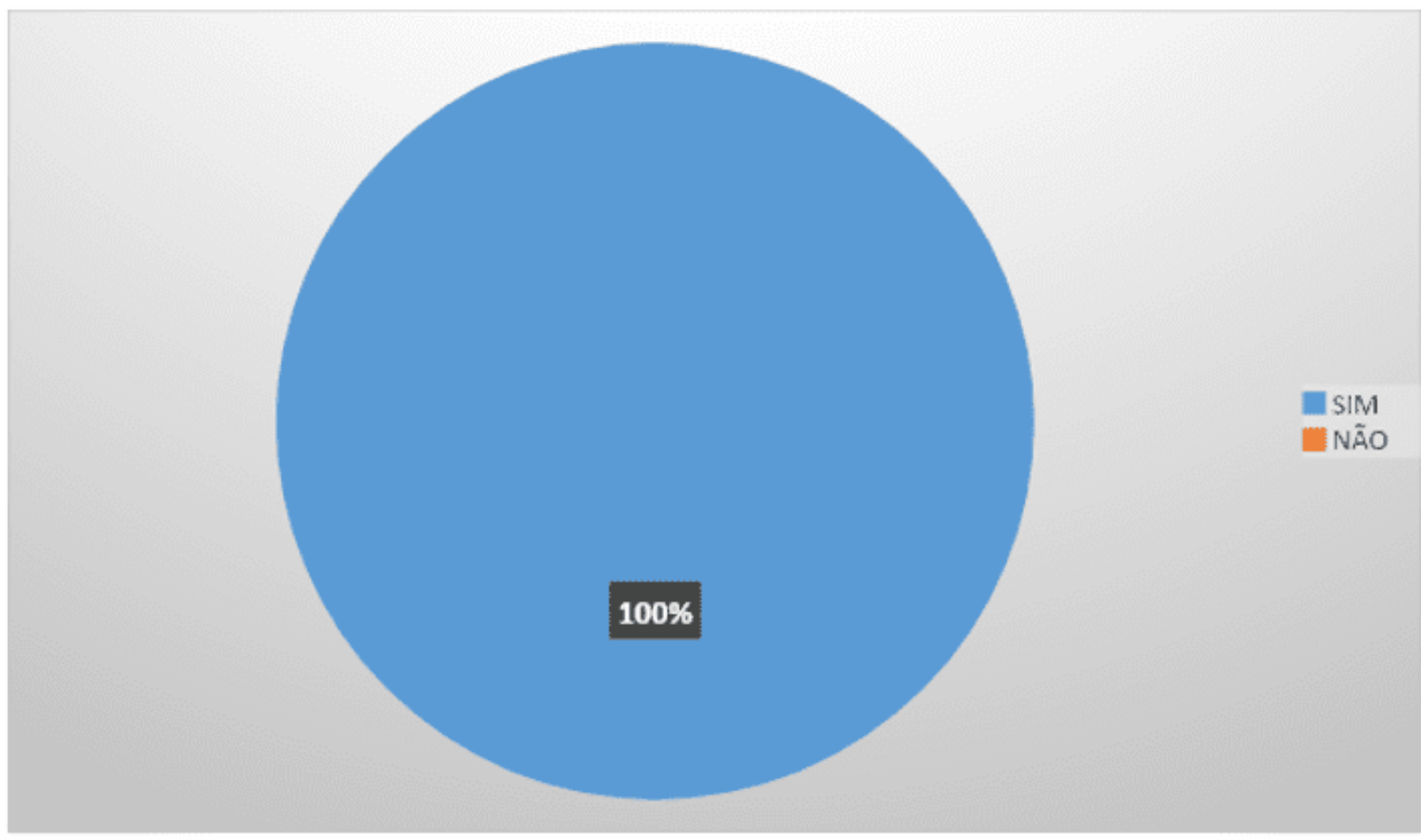

Fonte: Estudantes da modalidade da EJA em uma escola estadual em Lages/SC em 2019.

Todos os indivíduos participantes desta pesquisa relataram que consideram adequados o recurso utilizado pela professora para alfabetizá-los. Ao serem indagados do porquê? Tiveram a mesma resposta. Que ela ensina com atenção, carinho e que traz vivências deles mesmos, facilitando assim a compreensão do que estão aprendendo, além de conversar e se distrair depois de um dia cansativo que normalmente tem.

O diálogo na relação pedagógica vai ajudar os (as) educandos (as) a organizar reflexivamente o seu pensamento inserindo-o no processo histórico, fazendo com que renuncie seu papel de simples objeto e exigindo a sua atuação enquanto sujeito, pois, para que aconteça a real educação, a principal forma de comunicação é o diálogo. (LOSSO, 2012, p.192). 
Durante as observações demonstraram muito afeto pela professora, e contentes como ela media as aulas e os recursos que usa para esse fim. É preciso insistir que tudo quanto é feito em aula, por menor que seja, incide em maior ou menor grau na formação dos alunos.

A maneira de organizar a aula, o tipo de incentivos, as expectativas que depositamos, os materiais que utilizamos, cada uma destas decisões veicula determinadas experiências educativas, e é possível que nem sempre estejam em consonância com o pensamento que temos a respeito do sentido e do papel que hoje em dia tem a educação (ZABALA, 1998, p. 29).

A aula para ser construtiva se norteia por uma série de fatores que se bem elaborada, contribui positivamente no processo de ensino e aprendizagem. Os fatores que se fazem fundamentais nesse processo são: materiais didáticos, estratégias de ensino, diálogo, formação do professor, um olhar específico para seu público, metodologias de acordo com a modalidade de ensino.

A professora respondente da pesquisa, foi indagada sobre a questão da alfabetização na modalidade da EJA, juntamente a questões pertinentes que estão envolvidas nesse processo. Sabendo do quão abrangente é alfabetizar um sujeito, compreendese que essa condição perpassa ao simples fato de ler e escrever como afirma Soares (2004 p. 97). "Alfabetizar é muito mais que apenas ensinar a codificar e decodificar, e outras semelhantes". É preciso que práticas e métodos sejam construídos e organizados de acordo com as peculiaridades dessa modalidade de ensino.

Quando perguntada a professora sobre as metodologias que ela utiliza para alfabetizar, a mesma relata que não é muito de usar o livro didático. Ela mostra interesse em buscar algo novo dizendo que: "gosto de trocar experiências com alguns colegas que já trabalham nessa área, e que são aposentados, ela diz também que acha muito bonito, coisa diferente, e que indaga diariamente seus estudantes se está bom ou se não está, e se de fato estão aprendendo". Ressaltando que o que vale não é quantidade mais sim qualidade no ensino. 
Nessa circunstância, ao perguntar como ela se avalia, descreveu que é uma boa professora, está ciente do que faz, assume aquilo que fala, e gostaria de aprender mais, além disso, classifica a si mesma com a nota 10. Aliás, ela aconselha aos professores a se valorizarem pois: "ser professor é fantástico, não é para qualquer um", indaga a professora. No ínterim das observações ficou muito evidente que a professora trabalhava com muita dedicação e carinho com seus estudantes, e que a relação dos estudantes com a professora é muito afetiva.

A adoção de metodologias diferenciadas é essencial para promover um melhor processo ensino-aprendizagem, principalmente quando se busca uma formação qualificada de profissionais na área do ensino. Incluindo o fato de que o cotidiano de docentes e alunos é bastante dinâmico, é de fundamental relevância a também dinamização das aulas (MEDEIROS; ROSA, 2009, p.5).

No campo da EJA, é necessário um pensar nas especificidades desse público, de modo a preencher as lacunas na aprendizagem. Desse modo é importante trabalhar com práticas educativas diferentes e estratégias distintas, pensadas de acordo com os estudantes, possibilitando assim condições de interação e desenvolvimento de senso crítico, se inserindo assim na sociedade com mais dignidade.

GRÁFICO 8: quais materiais são utilizados para alfabetizar?

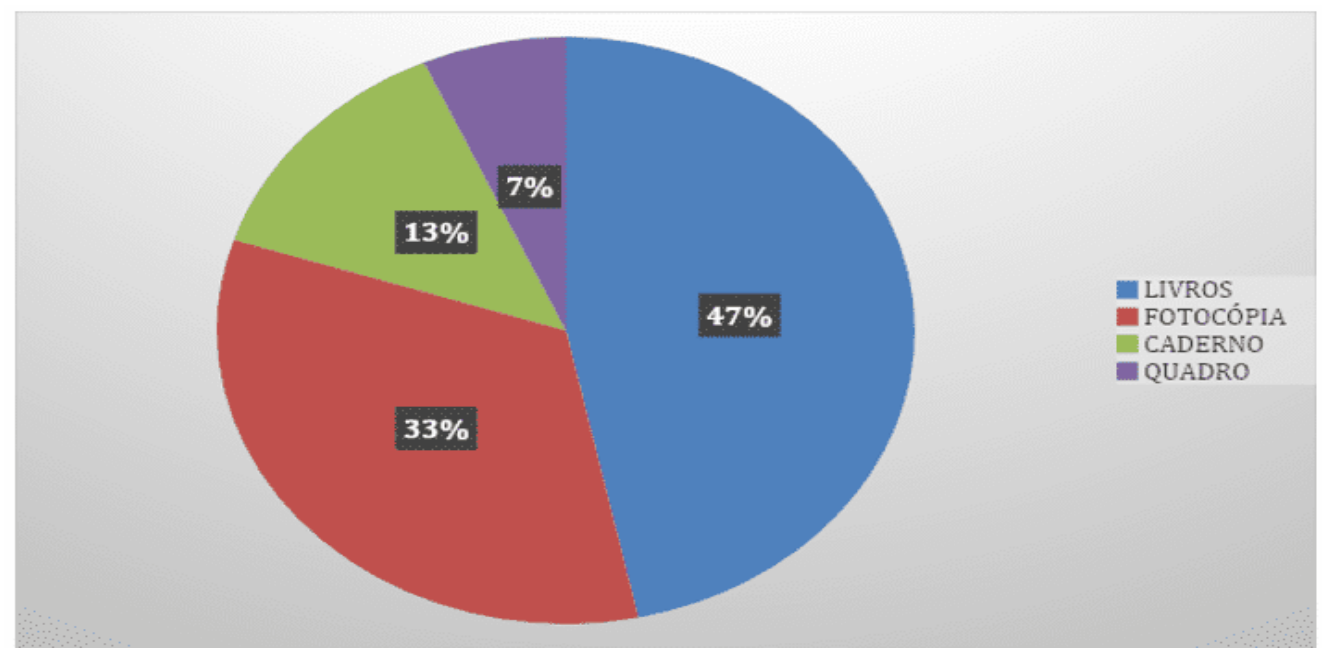

Fonte: Estudantes da modalidade da EJA em uma escola estadual em Lages/SC em 2019. 
Em conformidade com o gráfico, 47\% relatam que o professor utiliza o livro didático em suas aulas, $33 \%$ a fotocópia, $13 \%$ o caderno, e $7 \%$ o quadro.

É de suma importância a utilização de materiais didáticos, pois facilita no processo de ensino aprendizagem, além de estimular o interesse dos alunos fazendo com que tenham maior interação com o conteúdo, consequentemente, deixando as aulas mais dinâmicas e produtivas.

No universo da educação, a utilização de recursos didáticos e da tecnologia inovadora, somados a prática pedagógica adequada, busca despertar o interesse para o aprendizado, pois oferecem um conjunto de recursos importantes e ferramentas de comunicação e informações, tornando-se, assim, um componente essencial de pesquisa e um potente instrumento de ensino-aprendizagem (JUSTINO, 2011, p. 73)

Ainda que o docente utilize de todos os materiais didáticos possíveis, o professor só terá êxito com a utilização desses recursos de forma adequada, ou seja, é preciso pensar na idade, e nas dificuldades para que o professor não infantilize seu aluno jovem ou adulto, dessa forma, se faz presente o planejamento.

Como mostra o gráfico, o material mais utilizado em sala de aula foi o livro didático com $47 \%$. Que por sua vez não dá conta de todas as necessidades, trabalhando somente com aquilo que já está pronto,

conforme afirma Kuenzer (2002, p.301):

(...) o trabalhador se educa no e a partir do seu processo de trabalho, com apoio da formação teórica adquirida nos cursos de formação inicial e continuada; mas é no trabalho, e através das relações estabelecidas a partir dele, que se constroem as competências profissionais, pela articulação entre conhecimento e intervenção.

Os materiais didáticos, são recursos fundamentais no processo de ensino/aprendizagem, pois são eles que irão motivar, dinamizar e causar interesse pelos mesmos nas aulas, como afirma Souza (2007, p. 110):

[...] o professor poderá concluir juntamente com seus alunos, que o uso dos recursos didáticos é muito importante para uma melhor aplicação do conteúdo, e que, uma maneira de verificar isso é na aplicação das aulas, 
onde poderá ser verificada a interação do aluno com o conteúdo. Os educadores devem concluir que o uso de recursos didáticos deve servir de auxílio para que no futuro seus alunos aprofundem e ampliem seus conhecimentos e produzem outros conhecimentos a partir desses. Ao professor cabe, portanto, saber que o material mais adequado deve ser construído, sendo assim, o aluno terá oportunidade de aprender de forma mais efetiva e dinâmica.

O livro didático é um material pedagógico, que contém muitos conhecimentos, e dão suporte para o educador, mas, é impossível utilizar somente uma estratégia no momento da mediação. Faz-se necessário, trazer uma mescla de materiais em sala, fazendo com que a aula seja uma surpresa a cada dia. Dessa maneira, a propósito da possibilidade de educar de modo significativo na EJA, há de se concordar com Fuck quando afirma:

[...] não será possível se continuarmos bitolando os alfabetizando com desenhos pré formulados para colorir, com textos criados por outros para copiarem, com caminhos pontilhados para seguir, com histórias que alienam, com métodos que não levam em conta a lógica de quem aprende (FUCK, 1994, p. 14-15).

Juntamente com a reflexão de Fuck (1994) fica evidente que uma prática equivocada não auxilia na emancipação do sujeito. Nesse caso trabalhando mais o livro, os estudantes podem ficar desmotivados, e sem fazerem relação com o meio em que vivem, se tornando algo muito longe para eles, dificultando mais ainda a aprendizagem.

De outro modo, o uso de fotocópia com $33 \%$, pode ser um grande aliado para o educador. Em específico na modalidade da EJA, pois assim, podem compreender o processo de assinar e preencher um documento, com o acesso a fotocópia eles mesmos preenchem, marcam assinam o nome. Dá para planejar atividades com o propósito de educar, e relacionar com as necessidades do cotidiano.

[...] com a utilização de recursos didático-pedagógicos, pensa-se em preencher as lacunas que o ensino tradicional geralmente deixa, e com isso, além de expor o conteúdo uma forma diferenciada, fazer dos alunos participantes do processo de aprendizagem. (CASTOLDI e POLINARSKI, 2009, p. 685). 
Esses recursos são um dos principais meios para que ocorra o processo de ensino/aprendizagem. É nesse processo que o educador percebe se o material didático usado está realmente trazendo efeitos positivos.

caderno, com $13 \%$ usado pelo educador em sala, é um grande colaborador, com ele o educador planeja, faz anotações dos acontecimentos em sala, e seus registros, de acordo com Veiga (2006, p. 28):

Planejar o ensino significa pensar sobre algumas questões: Por quê, para quê e como ensinar? Quem ensina? Quem aprende? Quais os resultados do ensino? Mas não é só. É preciso ir além, a fim de evidenciar as relações entre os processos sociais que repercutem no ato de ensinar. O planejamento do ensino não constitui apenas uma expressão técnica e linear

Nas observações pôde-se notar que a professora tinha um caderno que abrangia muitas atividades, e planejamentos, o qual ela fez questão de mostrar. Esses registros são essenciais nesse processo, e ficam como forma de documento, pois lá pode constar informações bastante válidas sobre o deslanchar das atividades e também em relação ao processo de aprendizagem.

Os educandos, vem de forma histórica decorrente do uso de cadernos para fazerem as suas práticas e ações de forma em que os mesmos também anotem e façam as atividades copiando, manuseando o lápis, canetas e levando tarefa para casa, motivando-os a escrita e coordenação motora fina.

Da mesma forma o uso do quadro com $7 \%$ é um instrumento didático, muito usado pelos professores, considerado uma das "tecnologias" mais antigas relacionada a troca de saberes em sala de aula, e ainda podendo ser o único meio pedagógico usado em algumas escolas do Brasil. A importância do quadro é expressa por Hébrard (1995, p.6):

Os frades das escolas cristãs inventaram um instrumento do qual ainda não deixamos de nos servir: o quadro-negro. Esta superfície mal pintada, sobre a qual, com um pedaço de calcário fácil de conseguir na mineração das adjacências, o aluno é capaz de traçar letras ou números, é duradoura porque pode ser apagada. É o suporte privilegiado do 
exercício quando este se torna uma prática não mais dos colégios elitistas, mas das escolas destinadas à instrução de todas as crianças.

Esse instrumento, pode ser um grande recurso na explicação, pois com ele o professor faz traços, escritas e também consegue utilizar inúmeras vezes, por se tratar de um instrumento pedagógico que é capaz de ser apagado, quantas vezes for necessário.

Nessa pesquisa, os jovens e adultos responderam que a professora prepara as aulas através de livros, fotocópia, caderno e do quadro para alfabetizá-los, e tem total domínio sobre os conteúdos e atividades realizadas, sendo identificadas na observação.

GRÁFICO 9: dificuldades para se manter em sala de aula?

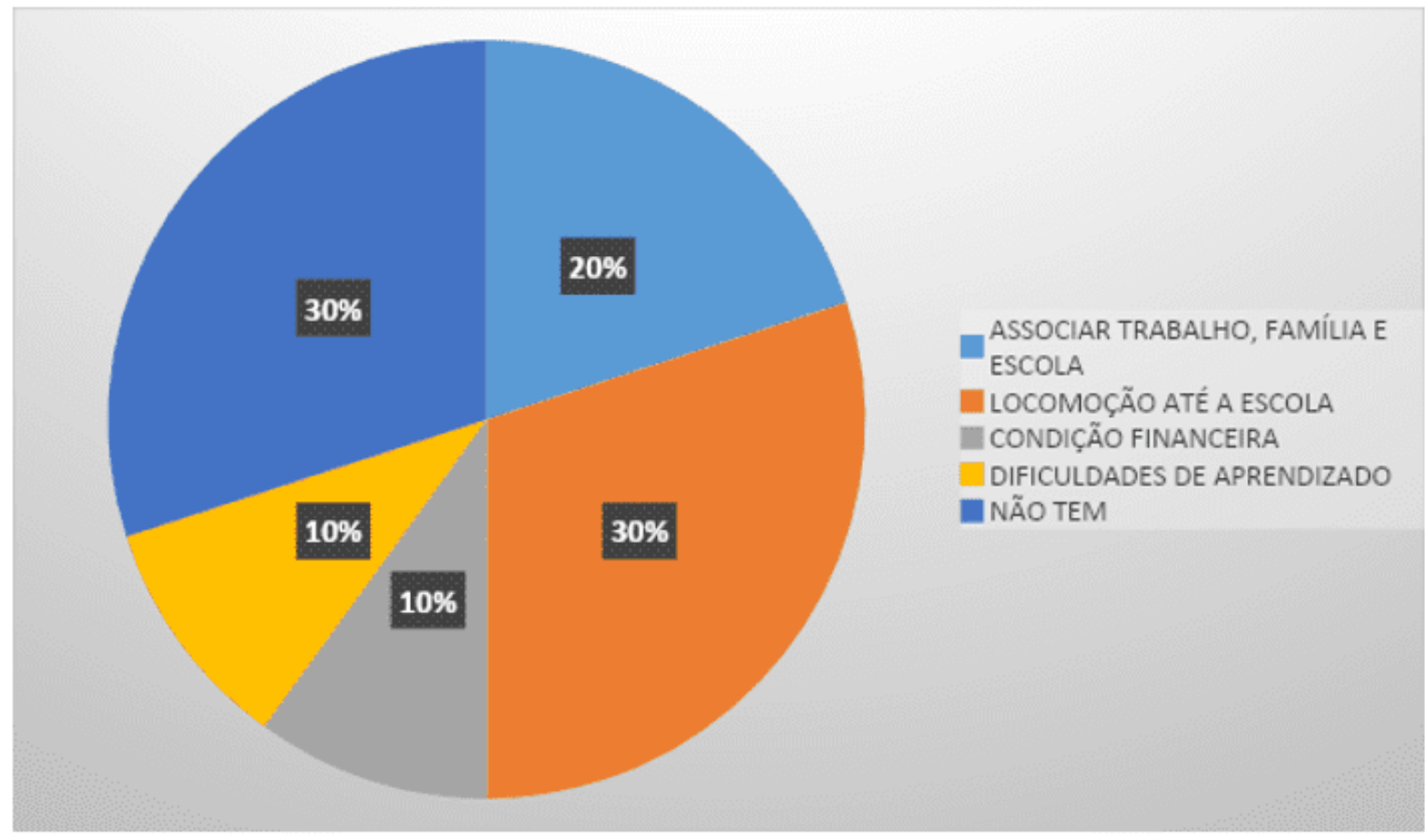

Fonte: Estudantes da modalidade da EJA em uma escola estadual em Lages/SC em 2019.

Dos dados apresentados referentes às dificuldades que os estudantes se encontram para manter-se em sala de aula, consta que 30\% não tem dificuldades para ir para a escola, sendo também $30 \%$ por falta de locomoção até o ambiente escolar. Os $20 \%$ descrevem que associar trabalho, família e escola é algo complicado, o gráfico mostra 
também 10\% apresentam dificuldades de aprendizado, e os $10 \%$ restantes pela condição financeira. Como Carvalho (1994, p.12) afirma:

Aluno matriculado no período noturno, na sua grande maioria, já está engajado em trabalho assalariado durante o dia, quase sempre em turno de oito horas. $O$ estudo à noite parece representar um prolongamento da jornada de trabalho, por mais quatro a cinco horas, tanto para o aluno, como, muitas vezes, para o professor. E o trabalho precoce desses alunos decorre da necessidade de sobrevivência das famílias das classes trabalhadoras no momento social que atravessamos.

Muitas vezes o trabalho do indivíduo ocorre em locais que necessitam de sua força braçal, ocasionando o cansaço e vontade de ir para seu lar, tendo que optar por frequentar a sala de aula ou descansar.

Dos entrevistados $10 \%$ descrevem que as dificuldades na aprendizagem contribuem na vontade em permanecer no espaço escolar, neste momento é indispensável o aperfeiçoamento dos materiais didáticos, para ajudar o estudante com dificuldades a se desenvolver e querer continuar frequentando as aulas em busca de novos saberes.

Segundo Santos (2007, p. 34) "os alunos que apresentam insegurança devido a suas superações e dificuldades no processo educacional, sentem-se desmotivados devido às metodologias e materiais utilizados fora do contexto em que estão inseridos". O autor ressalta a importância do professor na vida do estudante, sendo ele capaz de fazer o indivíduo manter- se na escola mesmo com as dificuldades, consequentemente, o educador com metodologias apropriadas irá fazer com que o estudante aprenda e tenha motivação pelas aulas.

De acordo com o gráfico, $10 \%$ correspondem a falta de condição financeira e dificuldades de aprendizagem como umas das dificuldades para indivíduo permanecer no ambiente escolar. Dessa forma, pode-se perceber durante as observações que muitos vêm sem alimentar-se para a escola e cansados devido o dia de serviço, condições que, dificultam ainda mais o aprendizado. Entretanto, mesmo pelos obstáculos enfrentados eles continuam em busca de seus objetivos pessoais sendo para tirar a $\mathrm{CNH}$, ajudar seus filhos na tarefa, adquirir um emprego ou promoção no trabalho. 
A maior demanda de jovens pelos cursos de EJA traz, como consequência, a dificuldade de o professor atender num mesmo espaço e tempo diferentes níveis de conhecimento e ritmos de aprendizagens. Em geral, as falas dos professores apontam para aceitação do aluno adulto, reconhecendo e valorizando o esforço diário para permanecer no curso, o esforço para aprender, para responder às tarefas e a manutenção da relação hierárquica professor $x$ aluno, no respeito com que $o$ adulto trata o mestre. (FERRARI, 2011, p. 1)

A professora regente foi abordada sobre quais dificuldades encontra para alfabetizar, ela declara que há dificuldades em relação a idade deles, que os mesmos têm uma "cabeça de pré ", em relação a aprendizagem. Em oposição a fala da professora o autor consolida que:

No entanto, é preciso olhar para os analfabetos como sujeitos [...] inteligentes, que desenvolveram estratégias de sobrevivência em uma cultura escrita sem estar adequadamente instrumentalizados para isso, resolvendo problemas, vivendo, trabalhando e amando (SCHWARTZ, 2010, p. 63).

Sabe-se das dificuldades que o analfabeto enfrenta, mas não se pode em hipótese alguma comparar o sujeito adulto com crianças que estão na pré-escola. Pois eles têm toda uma experiência de vida, e tem seus saberes e suas individualidades, são sujeitos maduros que buscaram estratégias de sobrevivência, em meio a uma sociedade alfabetizada. 
GRÁFICO 10: o que motiva a continuar na EJA

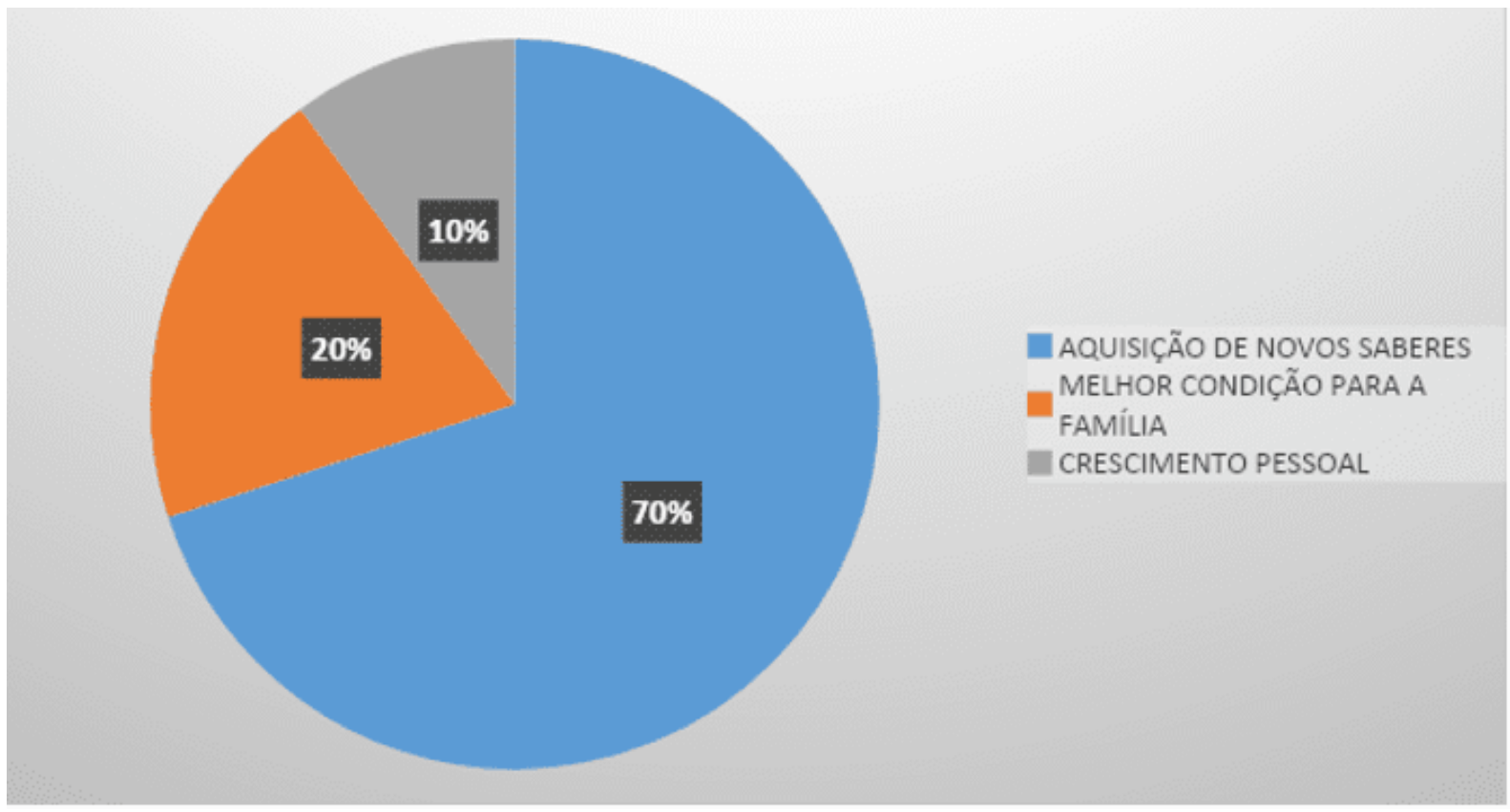

Fonte: Estudantes da modalidade da EJA em uma escola estadual em Lages/SC em 2019.

Ao serem indagados, $70 \%$ dos estudantes relataram que o que os motivam a continuar na EJA é aquisição de novos saberes. 20\% melhor condição para família, já 10\% o crescimento pessoal. Desse modo, repara-se que o motivo que mais evidenciou no gráfico foi a questão de adquirir novos saberes. Sabe-se da importância que é obter novos conhecimentos. Passar a ter diferentes visões, opiniões e conceitos de diversos assuntos e mais que isso, segundo Freire (2003, p.69):

Mulheres e homens, somos os únicos seres que, social e historicamente, nos tornamos capazes de aprender. Por isso, somos os únicos em que aprender é uma aventura criadora, algo por isso mesmo, muito mais rico do que meramente repetir a lição dada. Aprender para nós é construir, reconstruir, constatar para mudar o que não se faz sem abertura ao risco e à aventura do espírito.

Com a base na reflexão de Freire, todos podemos aprender, cada um com sua especificidade, no seu tempo. Basta buscar, querer, ir atrás. Descobrir conhecimentos novos, é uma dádiva da vida a qual todos podemos. 
O educador nesse processo é caminho entre o ensinar e o aprender, o qual tem um papel fundamental como mediador nesse processo, de tal forma que influencia o andamento dessa construção. Ademais vale destacar a importância de motivar o estudante nesse exercício educacional, como ressalta Coriá - Sabini (2000, p. 83), "motivação é a força propulsora da conduta. É a condição interna que ativa o indivíduo e o predispõe a emitir certas respostas".

O estudante motivado consequentemente tem mais interesse pela aula, o que traz mais ainda o gosto por aprender, acreditando que tem verdadeiras chances de mudar seu destino, com uma escolarização adequada, nascendo assim uma transformação na sua vida.

Dar continuidade nos bancos escolares depois de trajetória de ensino por vezes fragmentada e conturbada, é ter sonhos a frente, necessidades e desejos encontrados no passar da vida. Como apresentado no gráfico um dos motivos que faz esse público voltar à escola é dar uma condição melhor de vida, para si e para sua família, retomando uma etapa da vida.

Como consolida Gadotti (2007, p. 31): "os jovens e adultos trabalhadores lutam para superar suas condições precárias de vida (moradia, saúde, alimentação, transporte, emprego etc.) que estão na raiz do problema do analfabetismo". Antigamente os sujeitos começavam a trabalhar a partir dos 12 anos, sem nenhum tipo de exigência. Em tempos atuais o mercado de trabalho está bem mais criterioso, exigindo profissionais mais qualificados, fato esse que foi se modificando historicamente, pois a medida em que tempo passa vai ficando mais forte a questão de se preparar para o mercado de trabalho, sendo que muitos que começaram a trabalhar cedo, ficaram à margem do ensino.

O outro motivo, exposto no gráfico, é o crescimento pessoal. Os estudantes nessa modalidade de ensino voltam com vontade de progresso próprio, pois como afirma o autor:

Todas as pessoas almejam algo de bom. Provavelmente o sentido da felicidade, por ela ser subjetiva, seja particular e única para cada ser 
humano. Muitos fatores podem ser considerados como pilares para que alguém seja feliz, deve haver uma certa unanimidade em temas como saúde, escola, realização profissional, experiências afetivas e positivas. Uma das condições para se conseguir o bem-estar satisfatório consigo e com os outros é a autoestima. (KROTH, 2009, p. 2).

Um sonho, desejo, realizações e qualidade de vida são fatores que motivam os estudantes dessa área de ensino, fazendo com que fiquem no ambiente escolar.

GRÁFICO 11: relação com a professora

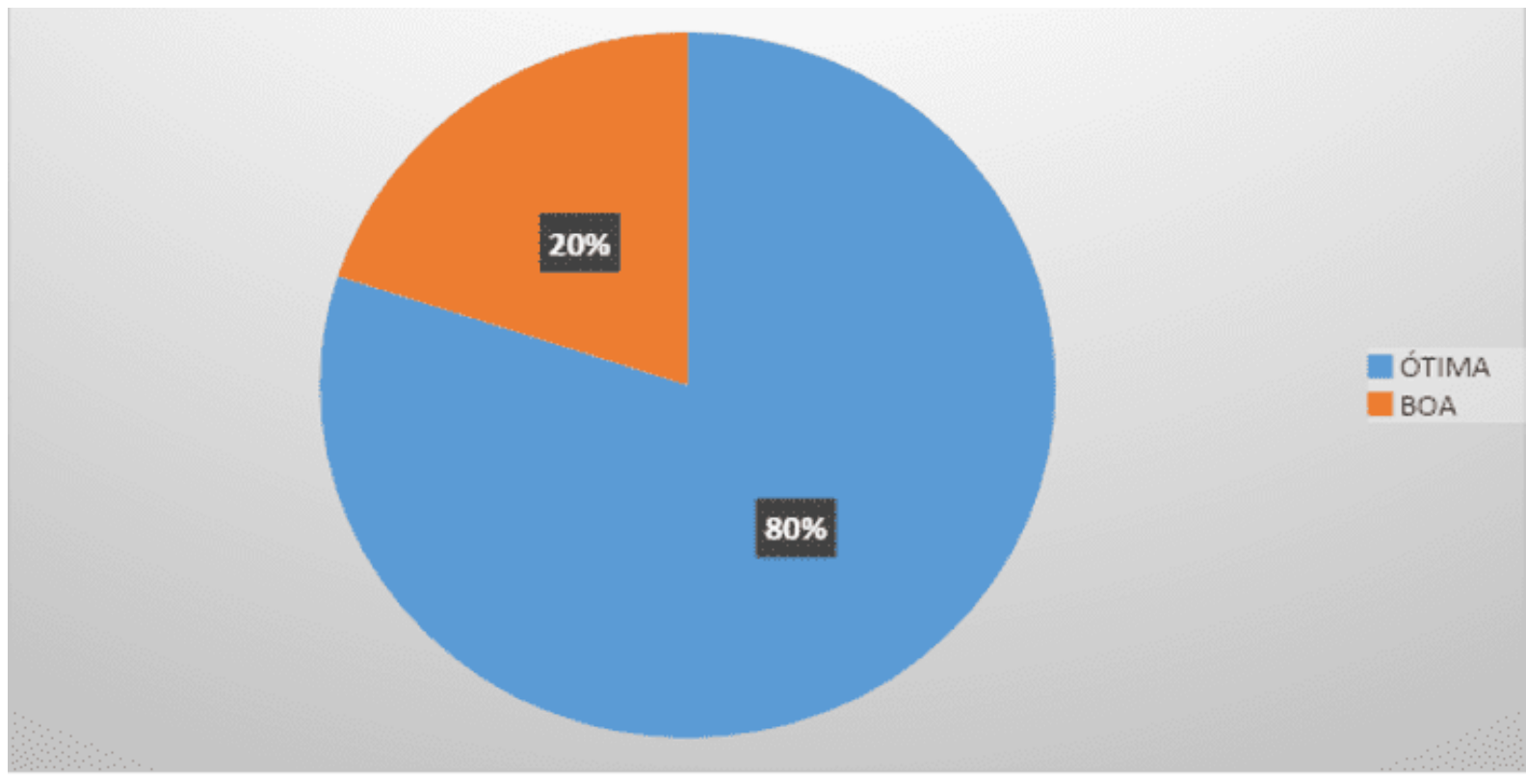

Fonte: Estudantes da modalidade da EJA em uma escola estadual em Lages/SC em 2019.

Entre os estudantes que responderam ao formulário sobre como é a sua relação em sala de aula com a professora, $80 \%$ responderam ser ótima e $20 \%$ uma relação boa, e todos afirmaram que a docente ensina bem, os respeita como seres humanos e é querida. A forma como o professor ensina e a sua relação com os estudantes, faz com que sintam interesse em permanecer no espaço escolar ou desistir. $O$ docente precisa se colocar no lugar dos indivíduos para entender suas dificuldades, sua bagagem cultural e o motivo de ele estar ali. Por meio do diálogo, o professor consegue essas informações para adequar os métodos que irá utilizar para alfabetizar os estudantes.

Miranda (2008, p. 2) descreve: 
A interação professor-aluno ultrapassa os limites profissionais e escolares, pois é uma relação que envolve sentimentos e deixa marcas para toda a vida. [...] a relação professor-aluno, deve sempre buscar a afetividade e a comunicação entre ambos, como base e forma de construção do conhecimento e do aspecto emocional.

Quando se busca estar em determinado lugar, se faz pelo sentido de sentir-se bem, assim é a escola, ambiente que deve fazer com que o estudante queira estar ali, buscando conhecimentos e sentindo-se parte da sociedade. A relação do professor com os estudantes precisa ser de parceria, de compreensão. Todos passaram por uma trajetória até chegarem ali, então, precisa ser um espaço onde além de ocorrer a aprendizagem, também possa ser um local de descanso e distração enquanto estiver em contato com os colegas e a docente.

Para Kullok (2002, p.11):

No processo de ensino-aprendizagem, o aluno é o sujeito e o construtor do processo. Toda aprendizagem precisa ser embasada em um bom relacionamento entre os elementos que participam do processo, ou seja, aluno, professor, colegas de turma, diálogo, colaboração, participação, trabalhos e jogos (brincadeiras) em conjunto ou em grupos, respeito mútuo $[\ldots]$.

Sendo assim, a relação que ocorre na sala de aula é capaz de interferir no desenvolvimento do estudante, se não se sentir à vontade e querer estar ali, além de desperdiçar tempo não irá aprender. Brandão (1983, p.72) afirma que "as expectativas negativas em relação aos alunos refletem-no desenvolvimento do aluno".

Já quando o estudante se sente em casa, ele não tem vergonha de perguntar sobre determinado assunto que esteja sendo ensinado, sendo este contato com a professora uma ligação de confiança e amizade, que é o que foi observado, fazendo com que o seu desenvolvimento seja mais rico de informações. Fonseca $(2007$, p.70) descreve que:

Ao perceber que a escola não apenas aceita, mas valoriza os conhecimentos que ele maneja com certa destreza, o aluno adulto sentese mais seguro, mais integrado ao fazer escolar e, principalmente, reconhece que tem valor por si mesmo e por suas decisões. 
Sendo respeitado os saberes e sua bagagem cultural de cada estudante, faz com que se sintam valorizados, e com ânimo de continuar a frequentar a escola em busca de novos saberes e da convivência com os colegas e a professora. É de suma importância no processo de ensino e aprendizagem um convívio amigável e afetivo entre o professor e o aluno, para garantir um ambiente sadio e harmonioso. Conforme afirma Tassoni $(2000$, p. 3):

Toda aprendizagem está impregnada de afetividade, já que ocorre a partir das interações sociais, num processo vincular. Pensando, especificamente, na aprendizagem escolar, a trama que se tece entre alunos, professores, conteúdo escolar, livros, escrita, etc. não acontece puramente no campo cognitivo. Existe uma base afetiva permeando essas relações.

O processo de ensino e aprendizagem vai muito além da presença de um professor dentro de sala de aula, é indispensável usufruir de afetividade, carinho e respeito, pois dessa forma desenvolve comunicação, interação e relações agradáveis.

Nesse contexto, é notório a relação boa e afável entre a professora e os estudantes da escola de Educação de Jovens e Adultos. Sendo assim, a professora avaliou a relação entre eles como ótima, contou que se dão muito bem, é brincalhona, conta piada, mas na hora de falar sério é sério e eles dispõem de total entendimento, existe respeito entre ambas partes. Segundo Martins et al (2005, p. 3), "A relação do professor-aluno tem que ser baseada no respeito mútuo, esse é o principal colaborar para tornar a sala de aula em um ambiente favorável à aprendizagem". O público da Educação de jovens e adultos por conter uma idade um pouco mais avançada, usufruir de inúmeras vivências, bagagens e culturas e o professor como mediador da turma precisa respeitar, para não cometer violência simbólica.

Dentro deste contexto, quando perguntado como ela avalia seus alunos, relatou que os avalia através da observação, contou também que ficou apenas seis meses com um rapaz em sua sala, pois analisando e observando percebeu o avanço no processo de alfabetização, "ele já estava escrevendo e lendo, continuava frequentando as aulas para tirar aquele tempo perdido de anos", à vista disso, a professora aprovou ele para o 5. ano, comentou também da alegria dele de ter trocado de turma. Ao perguntar 
como seus alunos se sentem em relação a atividades avaliativas confessou: "eles não gostam, brigam comigo, mas fazem!" Disse a professora.

\section{MÉTODOS UTILIZADOS PARA ALFABETIZAR}

$\mathrm{Na}$ elaboração dessa pesquisa, percebeu-se a necessidade de explanar e saber do conhecimento que o professor atuante na EJA tem sobre a andragogia. Esse modelo andragógico vem da necessidade de auxiliar no processo de ensino/aprendizagem de um estudante adulto, seus conceitos quando empregados em sala de aula podem enriquecer um aprendizado e torná-lo mais significativo, relevante e prático. Pois o estudante é elemento principal da construção do saber, seus pontos de vista e experiências são fatores essenciais para a construção do conhecimento. Enquanto que o educador nesse processo assume o papel de facilitador, um mentor que indica o caminho, gerando confiança entre ele e entre os estudantes.

Dessa forma, foi questionado a professora o que a mesma entende pelo conceito de andragogia. Visto que é de suma importância que o educador na modalidade da EJA, ter conhecimentos andragógicos, pelo fato em que essa ciência irá possibilitar um suporte na mediação correta para esse público, e que fará a diferenciação de ensinar crianças a educar adultos.

O modelo andragógico é um modelo processual, em oposição aos modelos baseados em conteúdo [...] O professor andragógico (...) prepara antecipadamente um conjunto de procedimentos para envolver os seguintes elementos: 1) preparar o aprendiz; 2) estabelecer um clima que leva à aprendizagem; 3) criar um mecanismo para o planejamento mútuo; 4) diagnosticar as necessidades para a aprendizagem; 5) formular os objetivos do programa (o conteúdo) que atenderão a essas necessidades; 6) desenhar um padrão para as experiências de aprendizagem; 7) conduzir essas experiências de aprendizagem com técnicas e materiais adequados; e 8) avaliar os resultados da aprendizagem e fazer um novo diagnóstico das necessidades de aprendizagem. (KNOWLES, 2009, p. 121-122).

A andragogia auxilia então nesse processo de conduzir a aprendizagem dos estudantes adultos. O professor que tem esse conhecimento andragógico, certamente trabalha de forma diferenciada, a partir de suas experiências e objetivos, exercitando 
conteúdos que lhe possibilitaram crescimento de vida, em se tratando da aprendizagem das pessoas jovens e adultas.

Nesse sentido De Aquino (2007, p. 11) afirma que:

Traduziu que a Andragogia [...] apresenta-se, atualmente, como uma alternativa à pedagogia e refere-se à educação centrada no aprendiz para pessoas de todas as idades. No modelo andragógico de aprendizagem, a responsabilidade pela aprendizagem é compartilhada entre professor e aluno, o que cria um alinhamento entre essa abordagem e a maioria dos adultos, que busca independência e responsabilidade por aquilo que julga ser importante.

Diante disso, indagamos a professora se ela já teve alguma formação na área da andragogia. A professora disse que nunca teve nenhum curso, ou estudos sobre esse conceito. Nesse caso ficou evidente a carência em questão a formação continuada para professores da EJA tendo em vista a importância que é o conhecimento andragógico nesse processo, juntamente com essa reflexão Soares (2006, p. 127), "[...] para compreendermos o processo de formação dos educadores, não podemos nos deter somente na formação inicial. É necessário ampliarmos o olhar sobre a trajetória dos educadores [...]". Nessa perspectiva, ressaltamos a formação continuada como base para essa reflexão, tornando-se desafio para a instituição formadora a partir do seu comprometimento com a construção de saberes no âmbito da EJA, revertido para os interesses dos sujeitos do processo educativo.

Desse modo, sem uma formação continuada a professora fica estagnada no tempo, os processos vão evoluindo, novos conceitos surgiram, que poderiam dar maior auxílio, aumentando as possibilidades em relação a aprendizagem em sala de aula. Mas se o professor não buscar, não estudar e pesquisar, certamente ficará preso ao ensino tradicional e homogêneo.

Ao entrevistar a professora em relação os métodos utilizados por ela, buscou-se identificar quais as metodologias são utilizadas na EJA para alfabetizar os estudantes.

Segundo Araújo (2006, p. 27): 
A metodologia de ensino - que envolve os métodos e as técnicas - é teórico-prática, ou seja, ela não pode ser pensada sem a prática, e não pode ser praticada sem ser pensada. De outro modo, a metodologia de ensino estrutura o que pode e precisa ser feito, assumindo, por conseguinte, uma dimensão orientadora e prescritiva quanto ao fazer pedagógico, bem como significa o processo que viabiliza a veiculação dos conteúdos entre o professor e o aluno, quando então manifesta a sua dimensão prática.

A metodologia é a forma como será mediado determinado conteúdo, e para que ocorra de forma eficaz é necessário que o professor seja pesquisador e faça um planejamento que contemple todos os estudantes, sempre refletindo se o método utilizado está dando resultados positivos na aprendizagem e se de fato os mesmos estão aprendendo.

Muitos professores se embasam em autores para amparar seus conhecimentos teóricos e por este motivo foi perguntado à professora participante se ela embasa seus planos em algum autor, como resposta ela informou que normalmente se embasa no Paulo Freire e Augusto Cury, debatendo sobre os livros desses dois autores. Sobre Paulo freire ela descreveu o fato de ele orientar como o professor precisa ser, nesse contexto, em uma de suas citações ele comenta:

Rigorosidade metódica, pesquisa, respeito aos saberes dos educandos, criticidade, ética e estética, corporificar as palavras pelo exemplo, assumir riscos, aceitar o novo, rejeitar qualquer forma de discriminação, reflexão crítica sobre a prática, reconhecimento e assunção da identidade cultural, ter consciência do inacabamento, reconhecer-se como um ser condicionado, respeitar a autonomia do ser educando, bom senso, humildade, tolerância, convicção de que mudar é possível, curiosidade, competência profissional (FREIRE, 1997, p. 14).

É necessário que o profissional da educação se coloque no lugar de seus estudantes para tentar compreender e auxiliá-los.

Nesse sentido Augusto Cury (2003, p.40):

Bons professores têm uma boa cultura acadêmica e transmitem com segurança e eloquência as informações em sala de aula. Os professores fascinantes ultrapassam essa meta. Eles procuram conhecer o funcionamento da mente dos alunos para educar melhor. Para eles, cada 
aluno não é mais um número na sala de aula, mas um ser humano complexo, com necessidades peculiares.

No autor citado pela professora, nota-se que busca qualidade ao invés de quantidade, respeita a diversidade em sala de aula e o tempo em que cada estudante leva para aprender.

Em relação aos materiais utilizados ela cita o livro didático, o PowerPoint, cartilhas, fotocópia, cruzadinhas, revistas para recortar e colar, convergindo assim com as respostas dos estudantes. Explica que seu planejamento ocorre por semestre, mas revisa semanalmente para analisar se precisa ser alterado, ou está acontecendo tudo como planejado. Dividido por tópicos, esclarece a professora. Ao perguntar se ela utilizava de alguma concepção de ensino, responde que não.

Seguindo com a entrevista, a professora foi questionada se utiliza de cartilhas para alfabetizar, a mesma relatou que recorre a cartilha de antigamente. Segundo Januzzi (1983, p.63) " era através de cartilhas ou livros de leitura, com gravuras das palavras geradoras, com as famílias silábicas e algumas palavras formadas pela junção dos fonemas geradores".

A cartilha um material didático muito comum antigamente, ainda ganha espaço nas salas de aula, usada principalmente para alfabetizar os adultos. Por vezes, tratando de um dos únicos suportes para o professor.

\section{CONSIDERAÇÕES FINAIS}

Este artigo pretendeu refletir sobre o Ensino de Jovens e Adultos em uma escola da cidade de Lages, SC, no que diz respeito às metodologias aplicadas e as dificuldades encontradas. Conforme os dados coletados apresentados por meio de gráficos e sua análise, o processo de ensino aprendizagem é mediado pela utilização de quadro, cartilhas e livros.

Os estudantes demonstraram a sua identidade de pessoas e estudantes extremamente diversas no que diz respeito ao gênero, motivos de retornarem ao EJA, 
as condições socioeconômicas de empobrecimento, estando aí o principal motivo do retorno aos estudos, melhorar a renda, as condições de vida.

O diálogo com a professora agregado aos aportes do referencial teórico, permitem afirmar que existem lacunas para se alcançar uma educação de melhor qualidade e melhorias nos processos de ensino aprendizagem na modalidade da EJA em Lages, SC. A formação continuada para professores desse público, ao delimitar o conhecimento apenas da experiência, desafiado na busca de novos saberes e fazeres na sua área de atuação, agregado a condição de Admitida em Caráter Temporário, impõe-se a necessidade de maior atenção e investimentos na Educação de Jovens e Adultos, uma modalidade de educação que detém um amplo público que ainda não exercita a educação como um direito de todos e um dever do Estado.

\section{REFERÊNCIAS}

ARAÚJO, José Carlos Souza. Do quadro negro à lousa virtual: tecnicas, tecnologia e tecnicismo. In VEIGA, Ilma Passos Alencastro (Org.) Técnicas de ensino: Novos tempos, novas configurações. Campinas: Papirus, 2006.

ARAÚJO, Silvia Maria de e outros. Sociologia: um olhar crítico. São Paulo: Contexto, 2009.

BRANDÃO, Zaia et al. Evasão e repetência no Brasil: a escola em questão. 15 ed. Rio de Janeiro: Achiamé, 1983.

BRASIL. Constituição da República Federativa do Brasil: promulgada em 5 de outubro de 1988. http://www.planalto.gov.br/ccivil_03/Constituicao/Constituiçao.htm. Acesso em: 08/11/2019.

BRASIL. Decreto-Lei no 9.394/96, de 20 de dezembro de 1996. Estabelece as Diretrizes e Bases da Educação Nacional. Disponível em: Acesso em: 29/09/2019.

BRASIL. Lei n.ำ 9394/96, de 20 de Dezembro de 1996. Lei de Diretrizes e Bases da Educação. Acesso: 10/04/2019. 
BRASIL. Ministério da Educação. Trabalhando com a educação de jovens e adultos: alunos e alunas da EJA. Brasília, MEC/SEF, 2006.

BUENO, M. S. S. (orgs). O Ensino Médio e a Reforma da Educação Básica, Ed. Plano, 2002.

CARVALHO, Célia P. Ensino Noturno: realidade e ilusão -7 ed. - São Paulo, Cortez, 1994.

CASTOLDI, R; POLINARSKI, C. A. A utilização de Recursos didático-pedagógicos na motivação da aprendizagem. In: II Simpósio Nacional de Ensino de Ciência e Tecnologia. Ponta Grossa, PR, 2009. Disponível em:< http://www.pg.utfpr.edu.br/sinect/anais/artigos/8\%20Ensinodecienciasnasseriesiniciai s/Ensinodecienci asnasseriesinicias_Artigo2.pdf>. Acesso em: 05/07/2019.

CÓRIA-SABINI, Maria Aparecida. Fundamentos de psicologia educacional. 2.ed. São Paulo: Ática, 2000.

CURY. Augusto Jorge, 1958-Pais brilhantes, professores fascinantes /Augusto Cury, - Rio de Janeiro: Sextante. 2000.

De AQUINO, C. T. E. Como aprender: Andragogia e as habilidades de aprendizagem. São Paulo: Pearson Prentice Hall, 2007.

FERRARI, S. C. O aluno de EJA: jovem ou adolescente? 2011. Disponível em: http://www.cereja.org.br/pdf/revista_v/Revista_ShirleyCostaFerra.pdf. Acesso em 06/11/2019.

FINI, Lucila Dichl Tolaine. Rendimento Escolar e Psicopedagogia. In Atuação Psicopedagógica e Aprendizagem Escolar. Orgs. Firmino Fernandes Sisto et al, Petrópolis, RJ: Vozes, 1996.

FONSECA, M. C. F. R. Educação Matemática de Jovens e Adultos: Especificidades, desafios e contribuições. Belo Horizonte: Autêntica. 2007. 
FREIRE, Paulo. Pedagogia da Autonomia: Saberes necessários à prática educativa. São Paulo: Paz e Terra, 1996.

FREIRE, Paulo. Pedagogia do oprimido. 24 ed. Rio de Janeiro: Paz e Terra, 1997. FUCK, Irene Terezinha. Alfabetização de Adultos. Relato de uma experiência construtivista. 2. ed. Petrópolis: Vozes, 1994.

GADOTTI, Moacir; ROMÃO, José E. (orgs.). Educação de Jovens e Adultos:Teoria,Prática e Proposta. 10. ed. São Paulo:Cortez: Instituto Paulo Freire. 2008.

HAYDT, Regina Cazaux. Avaliação do processo ensino - aprendizagem. Ed. Ática. 6ª edição: São Paulo: EPU, 2004.

HÉBRARD, J. A escolarização dos saberes elementares na época moderna. Teoria \& Educação, Porto Alegre, n. 2, 1990.

IBGE - Instituto Brasileiro de Geografia e estatística. PAS - Pesquisa Anual de Serviços, 2017. Disponível em: <https://agenciadenoticias.ibge.gov.br/agencianoticias/2012-agencia-de-noticias/noticias/21255-analfabetismo-cai-em-2017-massegue-acima-da-meta-para-2015>. Acesso em: 09/04/ 2019.

IBGE - Instituto Brasileiro de Geografia e estatística. PAS - Pesquisa Anual de Serviços, 2018. Disponível em: <https://agenciadenoticias.ibge.gov.br/agencia-salade-imprensa/2013-agencia-de-noticias/releases/22374-ibge-divulga-as-estimativasde-populacao-dos-municipios-para-2018>. Acesso em: 10/04/2019.

JANNUZZI, G. M. Confronto Pedagógico: Paulo Freire e MOBRAL. São Paulo, Ed. Cortez, 1983.

JUSTINO, Marinice Natal. Pesquisa e recursos didáticos na formação e prática docente. Curitiba: Ibpex, 2011. 
KNOWLES, Malcolm. Aprendizagem de resultados: uma abordagem prática para aumentar a efetividade da educação corporativa. 1‥ ed. Rio de Janeiro: Elsevier, 2009.

KROTH, Lídia Maria. Repetência e autoestima. São Paulo: nov. 2009. Disponível em: www.abpp.com.br. Acesso dia 07/11/2019.

KUENZER, A. Z. A escola desnuda: reflexões sobre a possibilidade de construir o ensino médio para os que vivem do trabalho. In: ZIBAS, D. M. L.; AGUIAR, M. A. de S.; BUENO, M. S. S. (Orgs.). O Ensino Médio e a reforma da Educação Básica. Brasília: Plano, 2002.

KULLOK, M.G.B. (Org). Relação professor - aluno. Contribuições à prática pedagógica. Maceió, Edufal, 2002.

LOSSO, Adriana Regina Sanceverino. Os sentidos da mediação na prática pedagógica da educação de jovens e adultos. São Leopoldo, RS: UNISINOS, 2012.

MARTIN, E; MARCHESI, A. Desenvolvimento metacognitivo e problemas de aprendizagem. Porto Alegre: Artes Médicas, 1996.

MEDEIROS, Jaqueline Pavelegini; ROSA, Elisa Araguayo. Plástico: um tema gerador para o ensino de polímeros, 2009.

MEKSENAS. Paulo. Sociologia da Educação: Uma introdução ao estudo da escola no processo de transformação social. 2 edição, São Paulo: cortez; 1992.

PARANÁ. SECRETARIA DE ESTADO DA EDUCAÇÃO. Diretrizes Curriculares para a Educação de Jovens e Adultos no Estado do Paraná. Curitiba, 2006. Disponível em: http://www.educadores.diaadia.pr.gov.br/arquivos/File/diretrizes/dce_eja.pdf. Acesso em: 07/11/2019. 
SCHWARTZ, Suzana. Alfabetização de jovens e adultos: teoria e prática. Petrópolis, RJ: Vozes, 2010.

SOARES, L., Pedagogia da Autonomia. 25a․ EDIÇÃO, São Paulo, Paz e Terra, 1996.

SOARES, Magda. Alfabetização e Letramento: caminhos e descaminhos. Revista Pátio. Porto Alegre, 2006.

SANTOS, Maria Aparecida Monte Tabor dos. A produção do sucesso na Educação de Jovens e Adultos: o caso de uma escola pública em Brazlândia - DF. Dissertação (Mestrado em Educação) Brasília: Universidade de Brasília, 2007.

SOUZA, S. E. O uso de recursos didáticos no ensino escolar. In: I Encontro de Pesquisa em Educação, Iv Jornada De Prática De Ensino, XIII Semana de Pedagogia da UEM, Maringá, 2007. Arq. Mudi. Periódicos. Disponível em: Acesso em: 07/10/2019.

TASSONI, E. C. M. Afetividade e aprendizagem: A relação professor-aluno. In: Psicologia, análise e crítica da prática educacional. Campinas: ANPED, 2000.

VEIGA, Amanda. Professor e Aluno: entenda a importância dessa relação. Par Plataforma $\quad 2018.2$ Disponível em: <https://www.somospar.com.br/professor-e-aluno/> Acesso em: 20/10/2019.

VEIGA, I.V. (org). Lições de Didática. São Paulo: Papirus, 2006

ZABALA, Antoni. A prática educativa: como ensinar. trad. Ernani F. da F. Rosa. Porto Alegre: ArtMed, 1998.

Enviado: Junho, 2020.

Aprovado: Outubro, 2020. 